\title{
PELUANG TERJADINYA TINDAK PIDANA KORUPSI AKIBAT PANDEMI WABAH COVID 19
}

\author{
Angga Pramodya P, S.H., M.H ${ }^{1}$ Meirza Aulia Chairani, S,H., M.H² \\ ${ }^{1}$ Program Studi Ilmu Hukum, Universitas Merdeka Madiun, Alamat Jalan Serayu No 79, Kota Madiun, Kode Pos \\ 63133 \\ E-mail: angga@unmer-madiun.ac.id \\ ${ }^{2}$ Program Studi Ilmu Hukum, Universitas Merdeka Madiun, Alamat Jalan Serayu No. 79, Kota Madiun, Kode Pos \\ 63133, E-mail: meirza.aulia@unmer-madiun.ac.id
}

\begin{abstract}
Abstrac-- Corruption during the Covid 19 pandemic led to the fact that many people experienced layoffs, employee reductions and the distribution of working hours for employees. This will have an impact on reducing income or not getting more income. This income reduction will lead to a criminal act, namely the Corruption Act, to fulfill the needs of oneself, others and corporations. This will affect the economy and harm the country's finances. The method used in this research is Normative Juridical. Based on the results of research on the perpetrators of corruption during this pandemic, it is very sensitive because everyone in the world is experiencing this pandemic and some people are making personal gains, others and corporations this needs to be given severe sanctions because during the Covid 19 pandemic they committed criminal corruption contained in Article 2 and Article 3 of the PTPK Law, and the penalty is added 1/3 (one third) of the main criminal.
\end{abstract}

KEY WORDS: Crime, Corruption, Covid Pandemic 19

\section{PENDAhUluan}

Di era globalisasi segala bentuk perbuatan atau tindakan semua sudah diatur dengan hukum, baik perbuatan yang dilarang maupun perbuatan yang boleh dilakukan diatur dalam hukum. Beberapa waktu ini di dunia di hebohkan dengan sebuah virus yang menyerah seluruh dunia yaitu Covid 19 atau yang dikenal dengan Virus Corona. Corona sendiri muncul di Kota Wuhan Cina pada Tahun 2019 dan menyebar keseluruh dunia. Berakibat pada penurunan bidang perekonomian, bidang insfrastruktur, bidang politik dan bidang-bidang lainya.

Beberapa perusahaan-perusahaan dan usaha-usaha kecil menengah banyak mengalami kebangkrutan akibat dari Covid 19 ini. Dampak dari Covid 19 seperti Pengurangan pegawai, Pemutusan Hubungan Kerja, dan lain sebagainya. Pengurangan pegawai dan Pemutusan Hubungan Kerja ini akan berdampak banyak terutama di bidang perekonomian. Hal ini mengakibatkan kurangnya pendapatan yang akan menimbulkan tindak pidana. Tindak pidana yang paling mencolok yaitu tindak pidana Korupsi.

Indonesia adalah era yang berdasarkan hukum yang bermakna Indonesia dalah negara hukum sebagai mana yang terdapat dalam Undang-Undang Dasar Republik Indonesia Tahun 1945 (selanjutnya disingkat UUD 45 ). Setiap perbuatan warganya diatur didalam hukum, karena hukum menetapkan apa yang harus dilakukan dan apa yang tidak boleh dilakukan.

Salah satu tindak pidana yang selalu menjadi sorotan di Indonesia adalah masalah korupsi. Korupsi bukanlah hal yang asing lagi di negeri ini. Korupsi di Indonesia bahkan sudah tergolong extra-ordinari crime atau kejahatan luar biasa karena telah merusak, tidak saja keuangan Negara dan potensi ekonomi Negara, tetapi juga telah meluluhkan pilar-pilar sosial budaya, moral, politik, dan tatanan hukum keamanan nasional. ${ }^{1}$

Di Indonesia sendiri sudah memiliki peraturan mengenai Pemberantasa Tindak Pidana Korupsu sejak Tahun 1971 yaitu Undang-Undang (UU) Nomor 3 Tahun 1971 tentang Pemberantasan Tindak Pidana Korupsi dan dirubah menjadi UU Nomor 31 Tahun 1999 Tentang Pemberantasan Tidnak Pidana Korupsi direvisi lagi dengan UU No 20 Tahun 2001 pada beberapa pasalnya.

${ }^{1}$ Ermansjah Djaja, 2010,Memberantas Korupsi Bersama KPK (Komisi Pemberantasan Korupsi), Sinar Grafika, Jakarta hlm. 13. Volume 7 Nomor 2 September 2021, YUSTISIA MERDEKA |86 
Virus Covid 19 yang melanda Indonesia akan menimbulkan akibat-akibat meningkatnya tindak pidana Korupsi karena faktor ekonomi yang semakin sulit. Faktor ekonomi akan mempengaruhi seseorang akan melakukan tindak pidana korupsi bagi beberapa orang yang memiliki jabatan dalam suatu pekerjaan.

Korupsi selalau bermula dan berkembang di sektor pemerintahan (publik) dan perusahan-perusahaan milik negara. Bukti-bukti yang nyata dengan kekuasan itulah pejabat publik dan perusahaan milik negara dapat menekan atau memeras para orang-orang yang memerlukan jasa pelayanan dari pemerintah maupun Badan Usaha Milik Negara (BUMN). ${ }^{2}$

Korupsi tidak hanya dalam lingkup pemerintahan namun juga dalam lingkup swasta pun terdapat korupsi, jika aktivitas bisnisnya terkait dengan sektor publik misalnya sektor perpajakan, perbankan dan pelayanan publik akan menjadi ladang tindak pidana korupsi.

Tindak pidana korupsi sudah sejak dulu menjadi momok menakutkan bagi suatu negara karena sangat merugikan negara dalam segala aspek. Oleh karena itu pemerintah berusaha untuk memberantasannya namun juga memerlukan peran serta masyarakat. Upaya penanggulangan korupsi dilakukan juga oleh organisasi sosial tertentu seperti ICW (Indonesian Corruption Watch). Peran serta masyarakat dalam menaggulangi Tindak Pidana Korupsi sangat membantu pemerintah dalam mengurangi Tindak Pidana Korupsi.

Berdasarkan tulisan diatas maka yang menjadi permasalahan dalam tulisan ini adalah:

1. Bagaimana dampak Pandemi Covid 19 terhadap Perekonomian Indonesia ?

2. Bagaimana pada saat pandemi Covid 19 ini ada oknum yang melakukan Tindak Pidana Korupsi?

\section{METODE PENELITIAN}

Metode penulisan dalam penelitian ini menggunakan penelitian normatif (Normative research). Pendekatan masalah yang digunakan dalam penelitian ini menggunakan pendekatan Perundang-undangan (Statute Approach) dan Pendekatan Konseptual (conceptual approach), dan Studi kasus (case study). Bahan hukum primer merupakan bahan hukum yang bersifat autoritatif, artinya mempunyai otoritas. Bahan hukum primer terdiri dari perundang-undangan, catatan-catatan resmi atau risalah dalam pembuatan undang-undang dan putusan-putusan hakim. ${ }^{3}$ Adapun bahan hukum primer yang digunakan dalam penelitian ini antara lain:

1. Undang-Undang Dasar Republik Indonesia Tahun 1945;

2. Undang -Undang Nomor 31 Tahun 1999 jo Undang - Undang Nomor 20 Tahun 2001 tentang Pemberantasan Tindak Pidana Korupsi;

3. Undang-Undang Nomor 1 Tahun 2004 tentang Perbendaharaan Negara;

4. Undang-Undang No 17 Tahun 2003 Tentang Keuangan Negara;

\section{PEMBAHASAN}

\section{A. Tindak Pidana Korupsi dalam keadaan Covid 19 terhadap Perekonomian Indonesia}

Menurut Fockema Andreae, kata Korupsi berawal dari bahasa latin corruptio atau corruptus. Corruptio berasal dari kata corrumpere, suatu kata latin yang lebih tua. Dari bahasa latin itulah turun ke banyak bahasa Eropa seperti Inggris yaitu corruption, corrupt; Prancis yaitu corruption; dan Belanda yaitu corruptie, korruptie. Dari Bahasa Belanda inilah kata itu turun ke Bahasa Indonesia yaitu korupsi. ${ }^{4}$

Dalam Black's Law Dictionary, korupsi adalah perbuatan yang dilakukan dengan maksud untuk memberikan suatu keuntungan yang tidak resmi dengan hak-hak dari pihak lain secara salah menggunakan jabatannya atau karakternya untuk mendapatkan suatu keuntungan untuk dirinya sendiri atau orang lain, berlawanan dengan kewajibannya dan hak-hak dari pihak lain. ${ }^{5}$

Tindak pidana korupsi dalam keadaan Covid 19 terhadap perekonomian Indonesia sangat berdampak besar. Dampak yang sangat mencolok yaitu Pemutusan Hubungan Kerja (PHK) oleh beberapa perusahan-perusahaan,

\footnotetext{
${ }^{2}$ Romli Atmasasmita,2004,Sekitar Korupsi Aspek Nasional dan Aspek Internasional, CV. Mandar Maju, Bandung hlm.1

3 Peter Mahmud Marzuki, Penelitian Hukum (Edisi Revisi), PT. Adhitya Andrebina Agung, Jakarta,2015, h. 181

4 Andi Hamzah, 2006,Pemberantasan Korupsi Melalui Hukum Pidana Nasional danInternasional, PT. Raja Grafindo Persada, Jakarta hlm 4

${ }^{5}$ Chaerudin DKK,2008,Strategi Pencegahan dan Penegakan Hukum Tindak PidanaKorupsi,PT Refika Aditama, Bandung, hlm 2
} 
pengurangan pegawai dan pengaturan waktu bekerja. Hal ini berdampak sekali dalam sektor perekonomian. Kehilangan mata pencarian dan berkurangnya pendapatan akan menimbulkan suatu dampak negatif berupa Tindak Pidana Korupsi dan tindak pidana lainya.

Dari bentuk-betuk Tindak Pidana Korupsi diatas semuanya dapat dilakukan dalam keadaan Covid 19 ini karena perekonomian yang susah untuk menyambung hidup beberapa orang akan melakukan hal-hal yang dilarang dalam hukum. PHK besar-besaran,penguranagn pegawai, penurunan jumlah uang yang didapat, beberapa tungakantungakan yang belum dibayar, untuk pangan dan kebutuhan-kebutuhan lainnya yang sebelumnya sudah mencukupi dalam keadaan Covid 19 ini tidak mencukupi. Hal ini dapat menimbulkan upaya Tindak Pidana Korupsi bagi mereka yang menduduki suatu jabatan.

Tindak Pidana korupsi ini merupakan perbuatan melawan hukum bagi siapa saja yang melakukan perbuatan ini akan dijerat dengan UU PTPK yang berlaku. Penyalahgunaan wewenang, dengan mempunyai kesempatan untuk melakukan tindak pidana dilakukan untuk memperkaya diri sendiri, orang lain atau suatu korporasi dan perbuatan terebut berakibat merugikan keuangan negara atau perekonomian negara.

Tindak pidana korupsi terdapat garis besar dalam memenuhi unsur-unsur sebagai berikut :

a. Perbuatan melawan hukum;

b. Penyalahgunaan wewenang, kesempatan atau sarana;

c. Memperkaya diri sendiri,orang lain atau korporasi; dan

d. Merugikan keuangan negara atau perekonomian.

Kerugian yang diterima bukan hanya instansi mereka bekerja namun juga negara terutama bidang perekonomian. UU PTPKsecara umum dari rumusan Pasal 2 dan Pasal 3.

Perbuatan melawan hukum ini merupakan perbuatan melawan hukum dalam arti formil maupun dalam arti materiil, jadi perbuatan tersebut tidak diatur dalam peraturan perundang-undangan namun apabila ada perbuatan tersebut dianggap tercela karena tidak sesuai dengan rasa keadilan atau norma-norma kehidupan sosial dalam masyarakat maka perbuatan tersebut dapat dipidana.

Memperkaya diri sendiri atau orang lain atau suatu korporasi, dalam keterangan UU PTPK memperkaya merupakan menjadikan lebih kaya dan memperkaya diri sendiri atau orang lain atau korporasi dalam Pasal 2 UU PTPK diisyaratkan bahwa perolehan atau penambahan kekayaan itu harus nyata adanya. ${ }^{6}$

Dapat merugikan keuangan negara atau perekonomian negara, bahwa tidak pidana korupsi cukup dengan dipenuhinya unsur-unsur perbuatan yang sudah dirumuskan bukan dengan timbulnya akibat. ${ }^{7}$

Kerugian negara atau daerah sebagaimana diatur dalam Pasal 1 angka 22 UU Nomor 1 Tahun 2004 tentang Perbendaharaan Negara, surat berharga, dan barang yang nyata dan pasti jumlahnya sebagai akibat perbuatan melawan hukum baik sengaja maupun lalai. Tindakan melanggar hukum yang dilakukan oleh pelaku dapat dikenakan sanksi untuk mengembalikan ganti kerugian dan juga tidak menutup kemungkinan untuk dituntut pidana.

Keuangan negara yang terdapat dalam Pasal 1 angka 1 UU No 17 Tahun 2003 adalah semua hak dan kewajiban negara yang dapat dinilai dengan uang, serta segala sesuatu baik berupa uang maupun berupa barang yang dapat dijadikan milik Negara berhubungan denga pelaksaksanaan hak dan kewajiban tersebut.

Perekonomian negara dalam penjelasan Pasal 2 UU PTPK menjelaskan :

"Perekonomian negara adalah kehidupan perekonomian negara yang disusun sebagai usaha bersama berdasarkan asas kekeluargaan ataupun usaha masyarakat secara mandiri yang didasarkan pada kebijakan pemerintah, baik ditingkat pusat maupun di daerah sesuai dengan ketentuan peraturan perundang-undangan yang berlaku yang bertujuan memberikan manfaat, kemakmuran, dan kesejahteraan kepada seluruh kehidupan masyarakat".

Tindak pidana korupsi dalam keadaan Covid 19 terhadap perekonomian Indonesia juga merupakan kerugian negara dalam hal ini jika dalam unsur-unsur dalam Pasal 2 dan Pasal 3 UU PTPK masuk dan perbuatan tersebut dikategorikan perbuatan melanggar hukum maka pelaku dapat dikenai sanksi.

\section{B. Pada saat Pandemi Covid 19 ini masih ada oknum yang melakukan Tindak Pidana Korupsi}

Pandemi Covid 19 saat ini yang menyerang seluruh dunia juga berdampak pada Indonesia. Banyak PHK, pengurangan pegawai dan pembagian waktu pekrja pegawai dalam hal ini akan ada banyak tindakan-tindakan kriminal yaitu salah satunya Tindak Pidana Korupsi.

\footnotetext{
${ }^{6}$ Amiruddin, 2010, Korupsi dalam Pengadaan Barang dan Jasa, Genta Publishing, Yogyakarta, hlm 155

${ }^{7}$ Ibid
} 
Dalam hukum tindak pidana korupsi terdapat subyek hukum yaitu subyek hukum orang dan subyek hukum korporasi. Dalam hukum pidana korupsi yang bersumber pada Undang -Undang Nomor 31 Tahun 1999 jo Undang Undang Nomor 20 Tahun 2001 tentang Pemberantasan Tindak Pidana Korupsi, subjek hukum orang ini ditentukan melalui 2 (dua) cara, yaitu: ${ }^{8}$

1. Cara pertama disebutkan sebagai subjek hukum orang pada umumnya, artinya tidak ditentukan kualitas pribadinya. Kata permulaan dalam kalimat rumusan tindak pidana yang menggambarkan atau menyebutkan subjek hukum tindak pidana orang pada umumnya, yang in casu tindak pidana korupsi disebutkan dengan perkataan "setiap orang" misalnya Pasal 2, 3, 21, dan 22, tetapi juga subjek hukum tindak pidana juga diletakkan di tengah rumusan misalnya Pasal 5 dan 6.

2. Sedangkan cara kedua menyebutkan kualitas pribadi dari subjek hukum orang tersebut, yang in casu ada banyak kualitasnya.

Subyek hukum korporasi menurut Mardjono Reksodiputro bahwa dalam perkembangan hukum pidana Indonesia ada tiga sistem pertanggungjawaban pidana terhadap korporasi sebagai subjek hukum tindak pidana, yaitu : ${ }^{9}$ 1. Jika pengurus korporasi sebagai pembuat, maka yang pengurus korporasi yang bertanggung jawab;

2. Jika korporasi sebagai pembuat, maka pengurus yangbertanggung jawab;

3. Jika korporasi sebagai pembuat dan korporasi yang bertanggung jawab.

Setidaknya ada tiga hal yang benar-benar harus dipahami oleh para praktisi hukum dalam menetapkan subjek hukum korporasi yang melakukan tindak pidana korupsi, yakni :

1. indikator kapan telah terjadi tindak pidana korupsi oleh korporasi;

2. secara sumir mengatur hukum acaranya;

3. mengenai pembebanan tanggung jawab pidananya.

Dari penjelasan diatas mengenai subyek hukum terdapat dua subyek hukum yaitu subyek hukum orang dan subyek hukum korporasi. Dalam pandemi Covid 19 ini karena masalah ekonomi pemasukan untuk pemenuhan kehidupan berkurang akhirnya mereka yang memegang suatu jabatan dalam pemerintahan ataupun swasta dapat melakukan tindak pidana korupsi.

Pelaku tindak pidana korupsi ini melakukan tindak pidana dalam keadaan pandemi Covid 19 ini karene akurangnya pemasukan karena banyak perusahaan yang mengurangi pegawai, PHK dan penjualan barang dan jasa perushaan menurun drastis kaibat Covid 19 ini.

Pemasukan penghasilan yang berkurang dan kebutuhan tetap tidak ada penurunan hal ini akan menjadi awal perbuatan kriminal seperti Tindak pidana korupsi ini. Pendapatan berkurang kebutuhan primer dan skunder tetap seperti makan, minum, listrik, kebutuhan sekolah, iuran-iuran dan lain sebagainya. Dari hal ini akan menimbulkan suatu perbuatan-perbuatan yang melanggar hukum.

Bila pelaku yang tertangkap atau di indikasi melakukan perbuatan melawan hukum dalam UU PTPK dapat dijatuhi hukuman yaitu :

a. Pidana mati

b. Pidana penajara

c. Pidana tambahan

Terhadap tindak pidana korupsi yang dilakukan oleh atau nama suatu korporasi yaitu dengan pidana pokok yang dapat dijatuhkan adlaah pidana dengan ketentuan maksimal ditambah 1/3 (sepertiga).

Oknum-oknum yang memanfaatkan pandemi Covid 19 ini untuk kepentingan diri sendiri, orang lain atau korporasi ini karena kurangnya pemasukan dan niat mereka untuk kepentingan pribadi orang lain dan korporasi ini merupakan perbuatan melawan hukum dan hal ini dapat dipidana sesuai UU PTPK yang berlaku.

\footnotetext{
${ }^{8}$ Adami Chazawi, 2005, Hukum Pidana Materiil dan Formil Korupsi di Indonesia, Bayumedia

Publishing, Malang, hlm 343-344

${ }^{9} \mathrm{Ibid}, \mathrm{hlm} 345$
} 


\section{KESIMPULAN}

Dari beberapa uraian pembahasan yang telah dipaparkan para peneliti sebagaimana tersebut diatas, dapat ditarik suatu kesimpulan antara lain sebagai berikut :

1. Tindak Pidana Korupsi dalam keadaan pandemi Covid 19 terhadap perekonomian sangat mempengaruhi dengan banyaknya orang pegawai perusahaan yang mengalami PHK, pengurangan pegawai dan pengurangan jam kerja hal ini akan mengakibatkan penurunan pendapatan dan mengakibatkan seseorang yang terdesak melakukan perbuatan Tindak Pidana Korupsi yang merugikan perekonomian suatu negara. Oleh karena itu dengan penyuluhan Tindak Pidana Korupsi ini bagi masyarakat mngetahui adanya sanksi berat bagi siapa saja yang melakukan Tindak Pidna Korupsi.

2. Dalam masa pandei Covid 19 ini orang akan melakuka apa sajaaga mendapatkan uang, hala maupun tidak halal misalnya melakukan Tindak Pidana Korupsi yang berakibat kerugian negara yang diguakan untuk diri senidiri, orang lain atau korporasi. Jadi seharusnya dalam masa pandemi Covid 19 ini semua orang mengalami kesusahan sebaiknya tidak melakukan tindak pidana korupsi.

\section{DAFTAR PUSTAKA}

\section{BUKU:}

Adami Chazawi, 2005, Hukum Pidana Materiil dan Formil Korupsi di Indonesia, Bayumedia Publishing, Malang

Andi Hamzah, 2006,Pemberantasan Korupsi Melalui Hukum Pidana Nasional danInternasional, PT. Raja Grafindo Persada

Amiruddin, 2010, Korupsi dalam Pengadaan Barang dan Jasa, Genta Publishing, Yogyakarta,

Chaerudin DKK,2008,Strategi Pencegahan dan Penegakan Hukum Tindak PidanaKorupsi,PT Refika Aditama, Bandung

Ermansjah Djaja, 2010,Memberantas Korupsi Bersama KPK (Komisi Pemberantasan Korupsi), Sinar Grafika, Jakarta

Peter Mahmud Marzuki, 2015,,Penelitian Hukum (Edisi Revisi), Jakarta:PT Adhitya Andrebina Agung,

Romli Atmasasmita,2004,Sekitar Korupsi Aspek Nasional dan Aspek Internasional, CV. Mandar Maju, Bandung

\section{INTERNET:}

https://id.wikipedia.org/wiki/Korupsi diakses pada 22 Maret 2020 Pukul 09.30 WIB 